Original Research Paper

\title{
ANSYS Numerical Modeling of Confined Deep Beam with High Strength Concrete
}

\author{
${ }^{1}$ Syahril Taufik, ${ }^{2}$ Elia Anggarini and ${ }^{2}$ Ichwan Setiawan \\ ${ }^{l}$ Department of Civil Engineering, Lambung Mangkurat University, Banjarmasin, Indonesia \\ ${ }^{2}$ Department of Civil Engineering, Muhammadiyah University, Banjarmasin, Indonesia
}

\author{
Article history \\ Received: 24-04-2019 \\ Revised: $15-07-2019$ \\ Accepted: 08-02-2020 \\ Corresponding Author: \\ Syahril Taufik \\ Department of Civil \\ Engineering, Lambung \\ Mangkurat University, \\ Banjarmasin, Indonesia \\ Email: staufik@ulm.ac.id
}

\begin{abstract}
In the numerical modeling presented, the deep beam is accounted for by means of a three dimensional FEA ANSYS 13.0 approach, in which the structure is modeled with load-displacement-based solid finite elements, whereas the internal work structure interacted by high strength concrete and reinforcement in full scale. Most deep beam collapse is dominated by the shear brittle collapse. Recently, confinement is the most effective way to improve the ductility of the reinforced concrete, whereas required to anticipate the occurrence of direct crack on the beam caused by quite large shear forces. Numerical models of deep beam with high strength concrete is done gradually by giving a variation of concrete strength, confinement and stirrup spacing. The two point load are applied with the ultimate load on all models. Then, analyzing of the deep beam is to be done with and without side reinforcement and also an analysis of the crack pattern of the beam to calculate the brittle area under the ratio of crack volume occurred. Concrete is modeled by SOLID65 and steel reinforcement using SOLID45 element. The collapses occurred are all ultimate flexural compressive collapse on the loading plate area, due to brittle shear collapse. The condition occurred on deep beam first crack was already considered a collapse, the density of reinforcement and the additional distance comprehensive reinforcement bar is most effective in terms of adding high ductility of high strength concrete beams. By using the stirrup reinforcement with confinement mode can significantly enhance the resistance of ultimate capacity, cracking ratio and reduced deflection.
\end{abstract}

Keywords: Numerical Modeling, ANSYS, Deep Beam, Brittle, Confinement, High Strength Concrete

\section{Introduction}

In deep beam, the dominant collapse is shear collapse, where collapse is brittle without a warning in the form of significant deflection. Shear collapse is caused by shear forces which result in sloping cracks in the beam and after this crack occurs, the shear force transfer mechanism will be contributed by arching action. This action can provide a quite large reserve capacity of the beam in carrying the burden (Sudarsana, 2006). Until now, the most effective way to increase the ductility of concrete is to provide confinement (Park and Paulay, 1975). Restraints are needed to anticipate the emergence of cracks directly on the beam caused by a fairly large shear force. High Strength Concrete (HSC) has high strength but low ductility, so special efforts are needed to improve ductility performance to be more earthquake resistant. Therefore, the study of the deep beam behavior with high strength concrete has been conducted using finite element method analysis with computational software programs.

The use of stirrups will increase the strength of the beam because the stirrup will carry most of the crosssectional shear force, the stirrup will hold back the development of the width of the crack diagonal and the cone that is quite tight will tie the concrete. Reinforced concrete will increase in strength when restrained. One of the factors that might influence curvature ductility is restraint (Kwan and Ho, 2010), where restraint is closely related to the reinforcement ratio.

The definition of deep beam according to ACI Code $318-2008$ is a beam that has a net span ratio equal to or less than four times the overall beam height for even loading or twice the effective height of the beam from the front of the placement for beams with centralized 
loading (Wight and MacGregor, 2009). If the beams that have a short sliding span with a ratio of the shear range and effective height of less than 2.0 for beams with simple support (simply supported beam) or less than 2.5 for beams that have a long span continuous beam (Park and Paulay, 1975).

Whereas according to Nawy, the definition of deep beam is a beam that has an effective ratio of shear span and beam height not exceeding 2.0 and 2.5 where the shear span is a net span of beam for evenly distributed loads with point load and less than 5.0 for evenly distributed loads.

High strength concrete has high compressive strength, durability and high ability to various environmental conditions. High strength concrete also has a high modulus of elasticity, low permeability and resistance to attack from some damage Neville and Aitcin (1998) and earthquake resistance (Azizinamini et al., 1994).

Architects and engineers wish to enlarge the spans of beam and increase moment of inertia by using slender structures. However, deep beams need enhanced stiffness to ensure a sufficient load-bearing capacity. This is usually realized with deeper beam structures and higher strength. Karthik (2009) implemented the effect of unconfined and confined concrete. Lertsrisakulrat et al. (2002) investigated a compressive failure of concrete in RC deep beams. Relationship between the compressive strength and modulus of elasticity of high-strength concrete is determined by Noguchi and Nemati (1991). Wu (2006) and Carrasquillo et al. (1981) investigated behavior of HSC members under various types of loading. The effects of confinement shapes on HSC beams have been determined by Hadi and Giongo (2008).

The main problem of deep beam mostly due to high shear force on the support area. Shear strength of deep RC beam has been experimentally determined by
Aguilar et al. (2002), Karayannis et al. (2005), Sudarsana (2006) and Arabzadeh and Aghayari (2001). Flexural behavior of HSC beams confined with stirrups in pure bending zone is effectively reduced (Jang et al., 2009).

The difficulty of conducting full scale destructive test in RC beam structure, could be minimized by FEM approach. ANSYS modeling of RC beam behaviour with stress contour plot and crack pattern have been investigated by Barbosa and Gabriel (1998), Sugianto and Taufik (2008) and Tjitradi et al. (2017). Delalibera et al. (2008) and Wolanski (2004) have conducted theorytical and numerical analysis of RC beam behavior.

The objectives of this study are as follows, analyzing the behavior of high strength concrete deep beams using finite element modeling by computational software programs. Analyzing the value of curvature ductility in high strength concrete beams that are influenced by confined restraint.

\section{Numerical Modeling}

ANSYS 13.0 computing software has been implemented for numerical modeling. Due to obtaining the real behavior in modeling, 3D full scale solid elements has been applied for all elements. The results of the analysis will be obtained in the form of nodal displacement, element forces, deflection, stress contour and crack pattern. In addition, crack patterns will occur in the first, second and third crack (ultimate crack). The RC beam models are set up with size 80/400 in mm under two point load, as shown in Fig. 1. The description of types elements for deep beam ANSYS input can be seen in Table 1 and 2, also in Fig. 2. The model are built by 29774 nodes with automatic mesh initially and then refined mesh.

Table 1: RC beam model in ANSYS

\begin{tabular}{llll}
\hline Material & Element & Dimension & Element Type \\
\hline Concrete & Beam & $800 \times 400 \mathrm{~mm}$ & SOLID 65 \\
Steel & Tension reinforcement & $1 \mathrm{D} 22\left(A_{s}=628 \mathrm{~mm}^{2}\right)$ & SOLID 45 \\
& Compressive reinforcement & $1 \mathrm{D} 12\left(A_{s}=628 \mathrm{~mm}^{2}\right)$ & \\
Steel & Shear reinforcement & $\phi 6-125 \mathrm{~mm}$ & SOLID 45 \\
Steel & Loading plate/ support & $200 \times 100 \times 50 \mathrm{~mm}$ & SOLID 45 \\
\hline
\end{tabular}

Table 2: Configuration of reinforcement in $\mathrm{RC}$ beam model $(\mathrm{L}=1600 \mathrm{~mm})$

\begin{tabular}{|c|c|c|c|c|c|}
\hline Beam ID & $f_{c}^{\prime}(\mathrm{MPa})$ & $\begin{array}{l}\text { Tension } \\
\text { reinforcement }\end{array}$ & $\begin{array}{l}\text { Compression } \\
\text { reinforcement }\end{array}$ & $\begin{array}{l}\text { Longitudinal } \\
\text { reinforcement }\end{array}$ & Stirrups \\
\hline DB.M1.65 & 65 & $1 \mathrm{D} 22$ & $1 \mathrm{D} 12$ & N/A & $1 \varnothing 6-215$ \\
\hline DB.M1.70 & 70 & & & & \\
\hline DB.M1.80 & 80 & & & & \\
\hline DB.M1.90 & 90 & & & & \\
\hline DB.M2.90 & 90 & $1 \mathrm{D} 22$ & 1D12 & N/A & $1 \varnothing 6-75$ \\
\hline DB.M3.90 & 90 & 1D22 & 1D12 & $1 \varnothing 12$ & $1 \varnothing 6-75$ \\
\hline DB.M3a.90 & 90 & 1D22 & 1D12 & $2 \varnothing 12$ & $1 \varnothing 8-75$ \\
\hline DB.M3b.90 & & & & & $2 \varnothing 6-75$ \\
\hline DB.M3c.90 & & & & & $2 \varnothing 8-75$ \\
\hline DB.M4.90 & & & & & $1 \varnothing 6-75$ \\
\hline
\end{tabular}


Syahril Taufik et al. / International Journal of Structural Glass and Advanced Materials Research 2020, Volume 4: 41.55 DOI: 10.3844/sgamrsp.2020.41.55
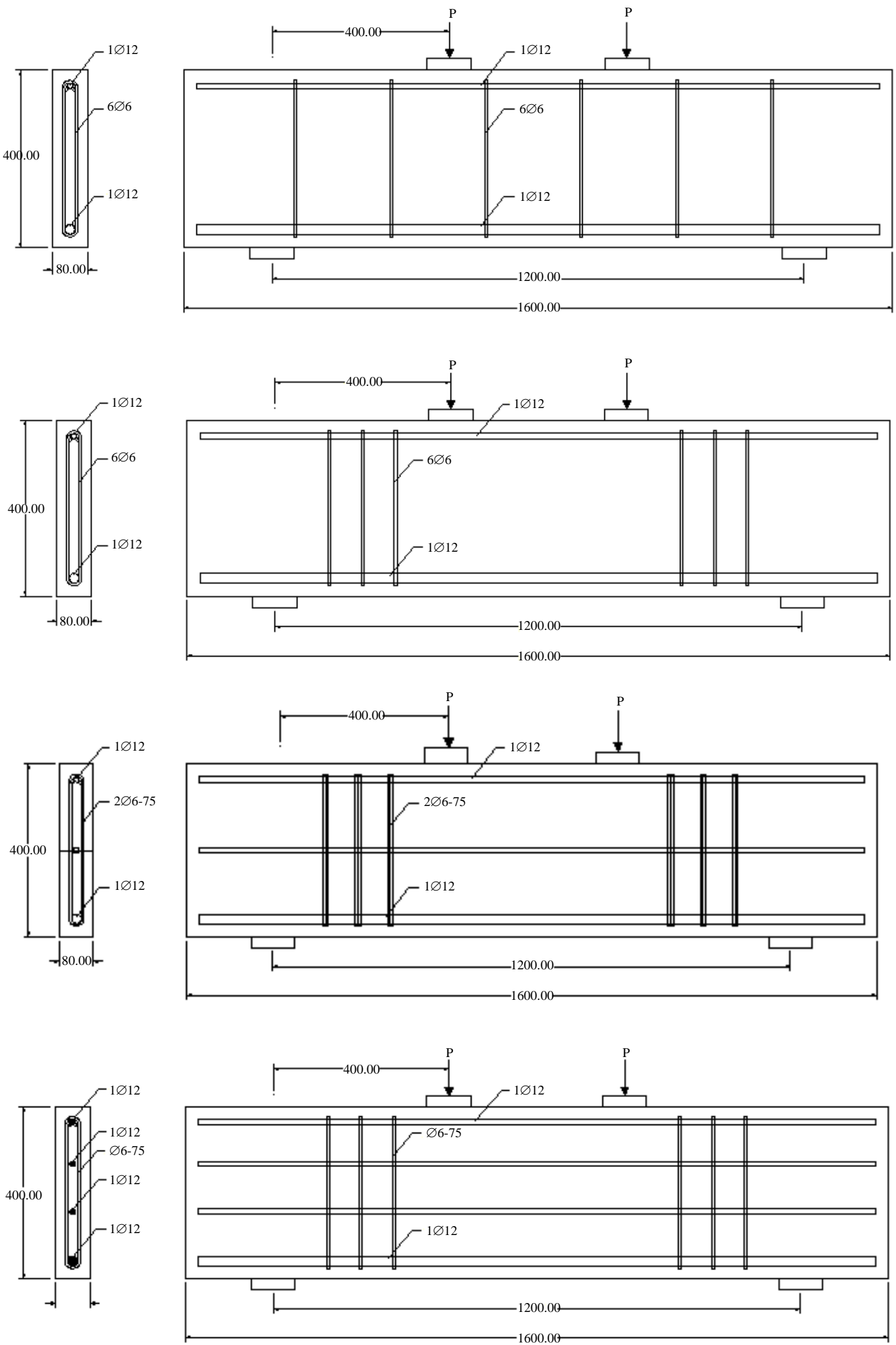

Fig. 1: Model of RC deep beams (M1, M2, M3, M4) 


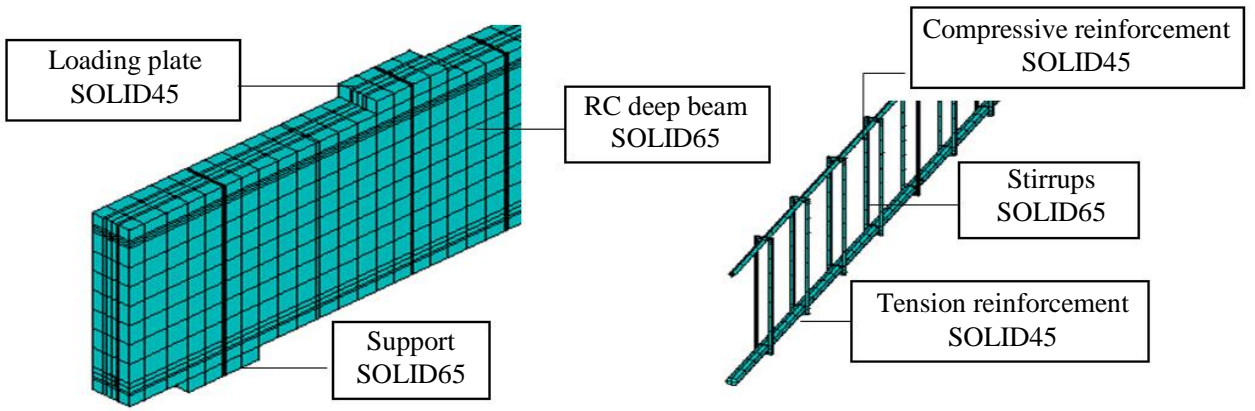

Fig. 2: Element types for ANSYS input

For high strength concrete, the value of modulus elasticity is derived from Equation 1 according to modified equation (Noguchi and Nemati, 1991) as follow:

$$
E=k_{1} k_{2} \cdot 3.35 \times 10^{4}(\gamma 2.4)^{2}\left(\sigma_{E} / 60\right)^{1 / 3}
$$

Where:

$E=$ Modulus of elasticity (MPa)

$k_{1}=$ Correction factor corresponding to course aggregate (0.902-1.027)

$k_{2}=$ Correction factor corresponding to admixture ( 0.95 or 1.00 or 1.05 )

$\gamma=$ Unit weight of concrete $\left(\mathrm{t} / \mathrm{m}^{3}\right)$

$\sigma_{B}=$ Compressive strength of concrete (MPa)

The value of stress-strain for high strength concrete are defined from Equation 2-4 according to Kent and Park model as follow:

$$
\begin{aligned}
& f_{c}=f_{c}^{\prime}\left[\frac{2 \varepsilon_{c}}{\varepsilon_{c u}}-\left(\frac{\varepsilon_{c}}{\varepsilon_{c u}}\right)^{2}\right] \text { for } \varepsilon_{c u} \leq 0.0025 \\
& f_{c}=f_{c}^{\prime}\left[1-Z\left(\varepsilon_{c}-\varepsilon_{c u}\right)\right] \text { for } \varepsilon_{c u}>0.0025 \\
& Z=\frac{0.5}{\varepsilon_{50 c}-\varepsilon_{c u}} ; E_{50 c}=\frac{3+0.29 f_{c}^{\prime}}{145 f_{c}^{\prime}-1000}
\end{aligned}
$$

Where:

$$
\begin{aligned}
f_{c}= & \text { Concrete stress }(\mathrm{MPa}) \\
f_{c}^{\prime}= & \text { Concrete strength }(\mathrm{MPa}) \\
\varepsilon_{c}= & \text { Concrete strain } \\
\varepsilon_{50 u}= & \text { Strain at } 50 \% \text { ultimate stress } \\
\varepsilon_{c u}= & \text { Ultimate strain }(0.25 \text { for } 60 \mathrm{MPa} ; 0.255 \text { for } 65 \\
& \mathrm{MPa} ; 0.26 \text { for } 70 \mathrm{MPa} ; 0.27 \text { for } 80 \mathrm{MPa} ; 0.28 \text { for } \\
& 90 \mathrm{MPa})
\end{aligned}
$$

Displacement ductility curvature of the RC deep beam is determined by Equation 5, regarding with the ratio of ultimate deflection and yield deflection:

$$
\mu_{d}=\delta_{u} / \delta_{y}
$$

Input material model for SOLID65 (concrete) element with concrete strength of $60 \mathrm{MPa}$ is depicted in Table 3. Modulus of elasticity is defined as $30.374 \mathrm{GPa}$, based on Equation 1. Stress-strain curve is plotted with piece wise linear as multi-linear kinematic hardening. Input of model material SOLID45 for steel reinforcement and loading plate are shown in Table 4 and 5.

\section{Modelling Simulation}

In order to conduct numerical modelling significantly, it has been firstly validated againts experimental of RC deep beam speciment A2 according to Arabzadeh and Aghayari (2001). The load deflection of experimental result againts ANSYS FE analysis is depicted in Fig. 3.

Different concrete strengths are applied in order to determine influence of higher strength concrete along with different configuration of shear reinforcements. The loaddeflection plot from developed FE modelling of deep beam with high strength concrete are depicted in Fig. 4.

The highest ultimate load of $570 \mathrm{kN}$ occured on the deep beam DB-M3-90 with the maximum midspan deflection of $6.141 \mathrm{~mm}$.

\section{Concrete Stress}

The results from FEM ANSYS software with the same load $P_{\text {ult }}=300 \mathrm{kN}$ in addition to yielding deflection values, can also provide von Misses equivalent stress of the beam as a whole due to various concrete compressive strength. This can also be clarified by reading the FEM results about the stresses that occur for each beam components. Overall concrete stress of the deep beams are summarized in Table 6 .

It can be concluded from Table 6 that by changing the stirrup spacing and adding longitudinal side reinforcement on the deep beam gives significantly various stress value. The value of stress on the beam given by two longitudinal reinforcement is lower than the other models that do not use longitudinal reinforcement and are only required 1 longitudinal side reinforcement. The beam model DBM1-65 with concrete strength of $f_{c}$ ' $=65 \mathrm{MPa}$, the yield stress $\left(f_{c y}\right)$ reached the value of $11.932 \mathrm{MPa}$, whilst the first crack stress occurs in the support area and under 
loading plate with the equivalent von Mises stress of $f_{c 1}$ $=36.772 \mathrm{MPa}$. The stress gradually starts from $0 \mathrm{MPa}$ at the end of the beam (right and left) until it reaches maximum at the point of loading. The maximum stress is occured below the loading plate with the value of $f_{c}=$ 64.744 MPa. The mechanism type of RC deep beam is likely reinforcement collapse. The stress contour can bee seen in Fig. 5.

Table 3: Input material for the SOLID65 (concrete) model

\begin{tabular}{ll}
\hline Modulus of elasticity & \multicolumn{1}{c}{ Poisson ratio $(\mathrm{v})$} \\
\hline $30.374 \mathrm{GPa}$ & 0.20 \\
Multilinear Kinematic Hardening & Stress $\left(f_{c}\right) \mathrm{MPa}$ \\
Strain $\left(\varepsilon_{\mathrm{c}}\right)$ & 12.756 \\
0.00042 & 17.003 \\
0.00055 & 25.454 \\
0.00083 & 33.741 \\
0.00111 & 41.621 \\
0.00137 & 45.292 \\
0.00149 & 48.702 \\
0.00160 & 51.782 \\
0.00170 & 54.461 \\
0.00179 & 48.702 \\
0.00160 & 51.782 \\
0.00170 & 54.461 \\
0.00179 & 56.670 \\
0.00186 & 58.350 \\
0.00192 & 59.456 \\
0.00195 & 60.000 \\
0.00250 & 59.964 \\
0.00252 & 58.344 \\
0.00266 & 50.101 \\
0.00294 & 39.156 \\
0.00320 & \\
SOLID65 (Concrete element) & \\
Open shear transfer coefficient \\
Closed shear transfer coefficient \\
Uniaxial cracking stress \\
Uniaxial crushing stress \\
Tensile crack factor \\
\multicolumn{2}{|}{} \\
\hline
\end{tabular}
Modified equation (Noguchi and Nemati, 1991)

High Strength Concrete

Table 4: Input of model material SOLID45 (Steel Reinforcement)

\begin{tabular}{ll}
\hline Linear Isotropic & $210 \mathrm{GPa}$ \\
Modulus elasticity of reinforcement $\left(E_{s}\right)$ & 0.30 \\
Poisson Ratio $(v)$ & $585 \mathrm{MPa}$ \\
Bilinear Isotropic Hardening & $433 \mathrm{MPa}$ \\
Yield strength $\left(f_{y}\right)$; Bar reinforcement $\varnothing 22 \mathrm{~mm}$ & $397 \mathrm{MPa}$ \\
Yield strength $\left(f_{y}\right) ;$ Bar reinforcement $\varnothing 12 \mathrm{~mm}$ & \\
Yield strength $\left(f_{y}\right) ;$ Stirrups $\left.\varnothing 6 \mathrm{~mm}\right)$ & \\
\hline
\end{tabular}

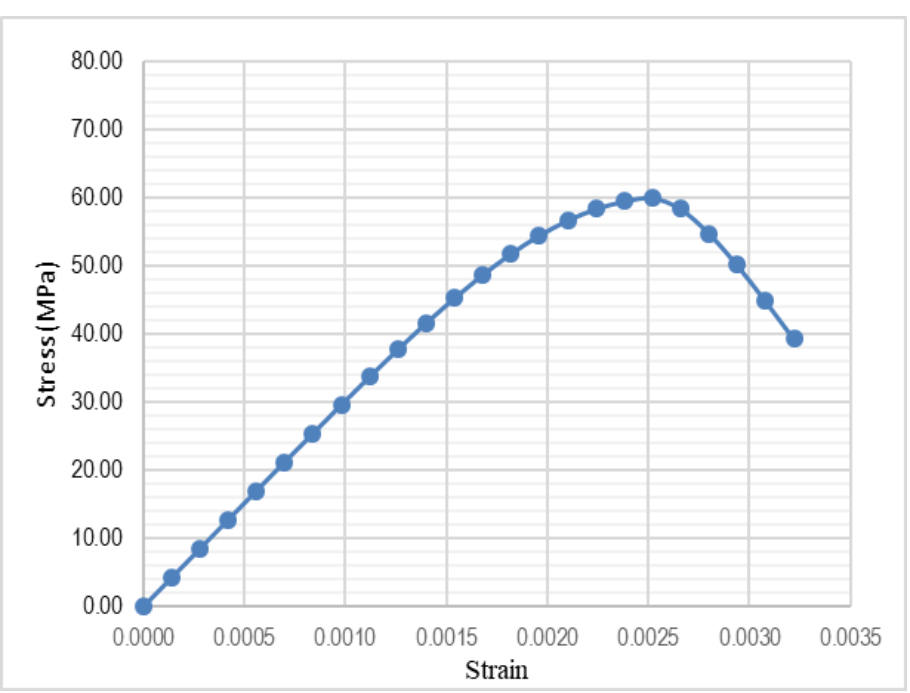

$\begin{array}{ll}0.20 \mathrm{MPa} & \\ 1.00 \mathrm{MPa} & \\ 4.5701 \mathrm{MPa} & 0.59 \sqrt{ } f_{c^{\prime}}(\mathrm{MPa}) \\ 60.00 \mathrm{MPa} & f_{c^{\prime}}(\mathrm{MPa}) \\ 0.60 & \end{array}$

Table 5: Input of SOLID45 model material (Support and Loading Plate)

Linear isotropic

Modulus elasticity of steel $\left(E_{s}\right)$

Poisson ratio $(v)$

Piecewise linear

$210 \mathrm{GPa}$

0.30

$f_{y}=397 \mathrm{MPa}$

Tabel 6: Concrete stress of deep beam

\begin{tabular}{lllllll}
\hline Beam ID & $f_{c}{ }^{\prime}(\mathrm{MPa})$ & $f_{c y}(\mathrm{MPa})$ & $f_{c 1}(\mathrm{MPa})$ & $f_{c u}(\mathrm{MPa})$ & $f_{c u} / f_{c}{ }^{\prime}$ & Collapse \\
\hline DB-M1-65 & 65.0 & 11.932 & 36.772 & 64.744 & 0.996 & Reinforcement \\
DB-M1-70 & 70.0 & 11.492 & 36.683 & 70.000 & 1.000 & Concrete \\
DB-M1-80 & 80.0 & 11.166 & 37.518 & 80.000 & 1.000 & Concrete \\
DB-M1-90 & 90.0 & 10.840 & 38.162 & 85.551 & 0.951 & Reinforcement \\
DB-M2-90 & 90.0 & 11.728 & 10.361 & 85.579 & 0.951 & Reinforcement \\
DB-M3-90 & 90.0 & 8.719 & 10.350 & 89.599 & 0.999 & Concrete \\
DB-M3a-90 & 90.0 & 10.866 & 10.017 & 89.944 & 0.999 & Concrete \\
DB-M3b-90 & 90.0 & 11.523 & 9.402 & 89.688 & 0.997 & Concrete \\
DB-M3c-90 & 90.0 & 12.719 & 9.037 & 89.798 & 0.998 & Concrete \\
DB-M4-90 & 90.0 & 11.691 & 10.320 & 71.459 & 0.794 & Reinforcement \\
\hline
\end{tabular}

$f_{c}{ }^{\prime}=$ compressive stress; $f_{c y}=$ yield Stress; $f_{c 1}=$ first crack stress; $f_{c u}=$ ultimate crack stress (all in $\left.\mathrm{MPa}\right)$ 
Syahril Taufik et al. / International Journal of Structural Glass and Advanced Materials Research 2020, Volume 4: 41.55 DOI: 10.3844/sgamrsp.2020.41.55

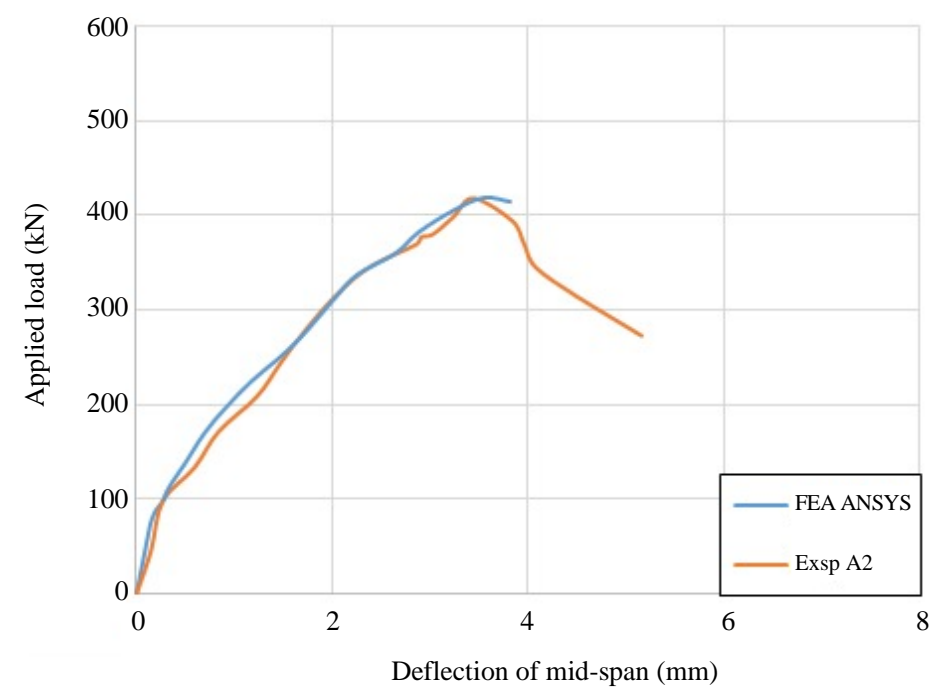

Fig. 3: Validation experimental A2 vs FEA ANSYS

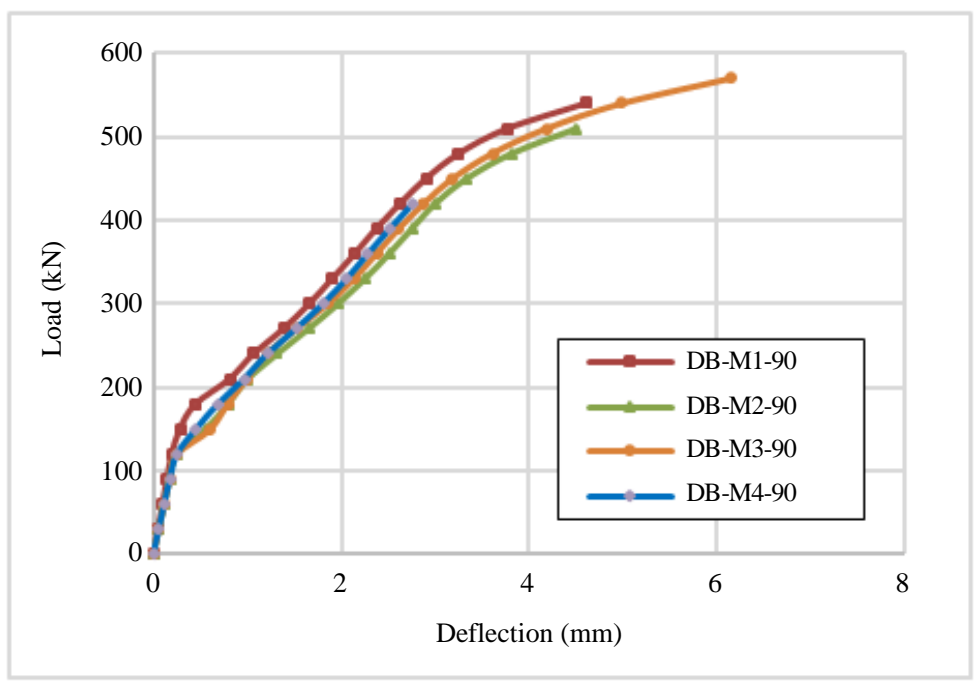

Fig. 4: Load-deflection plot of ANSYS developed model
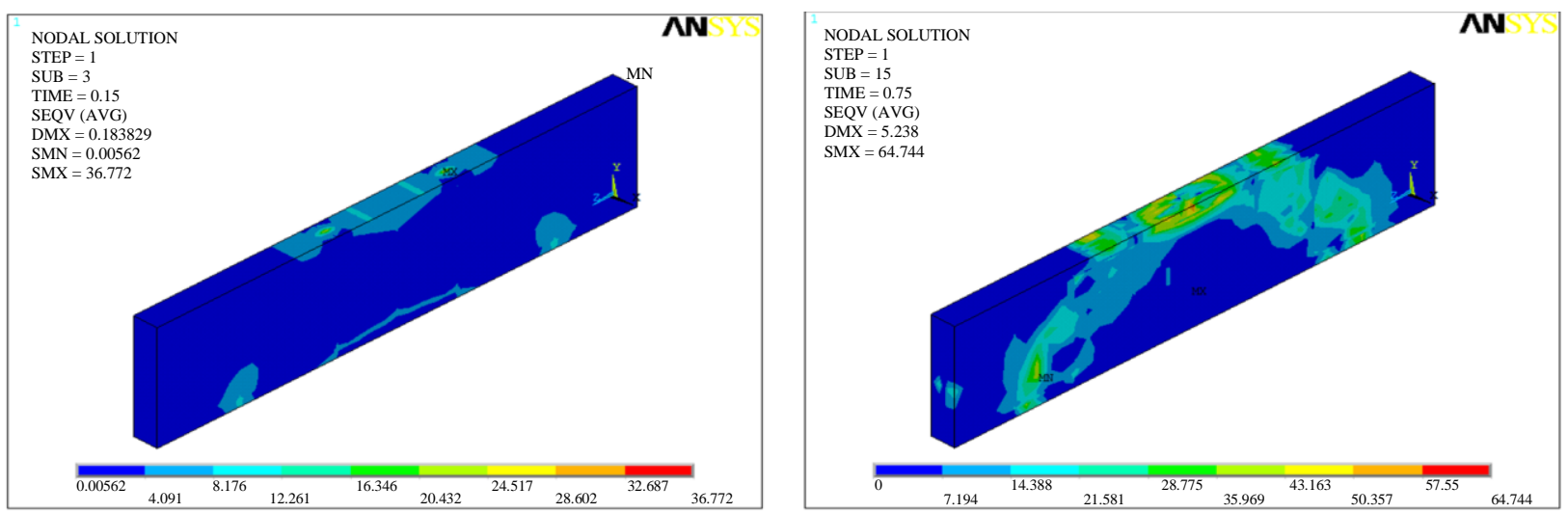

Fig. 5: DB-M1-65; first crack stress and ultimate stress 

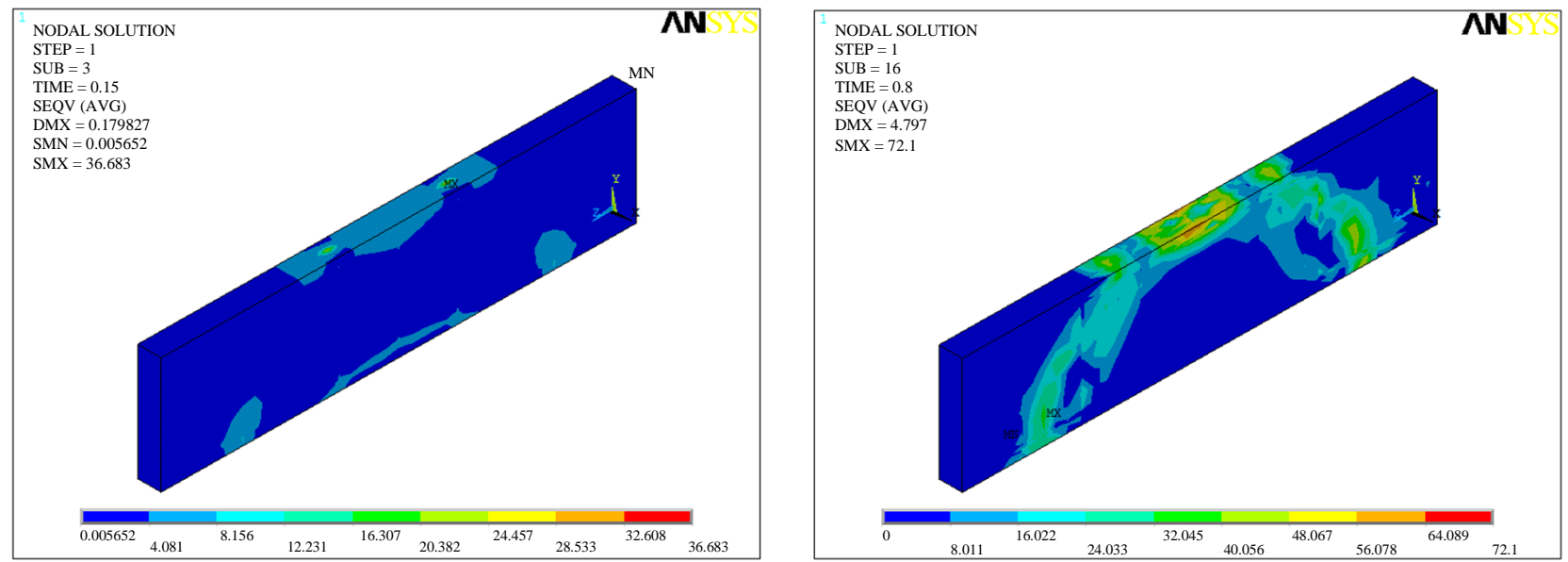

Fig. 6: DB-M1-70; first crack stress and ultimate stress
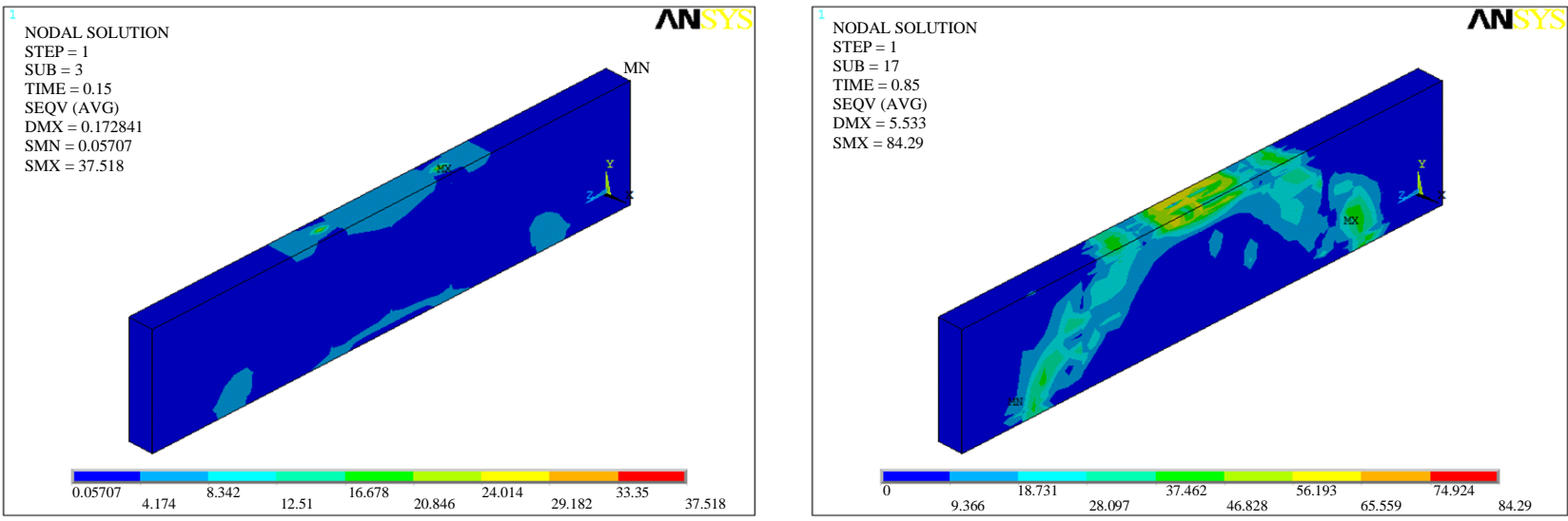

Fig. 7: DB-M1-80; first crack stress and ultimate stress
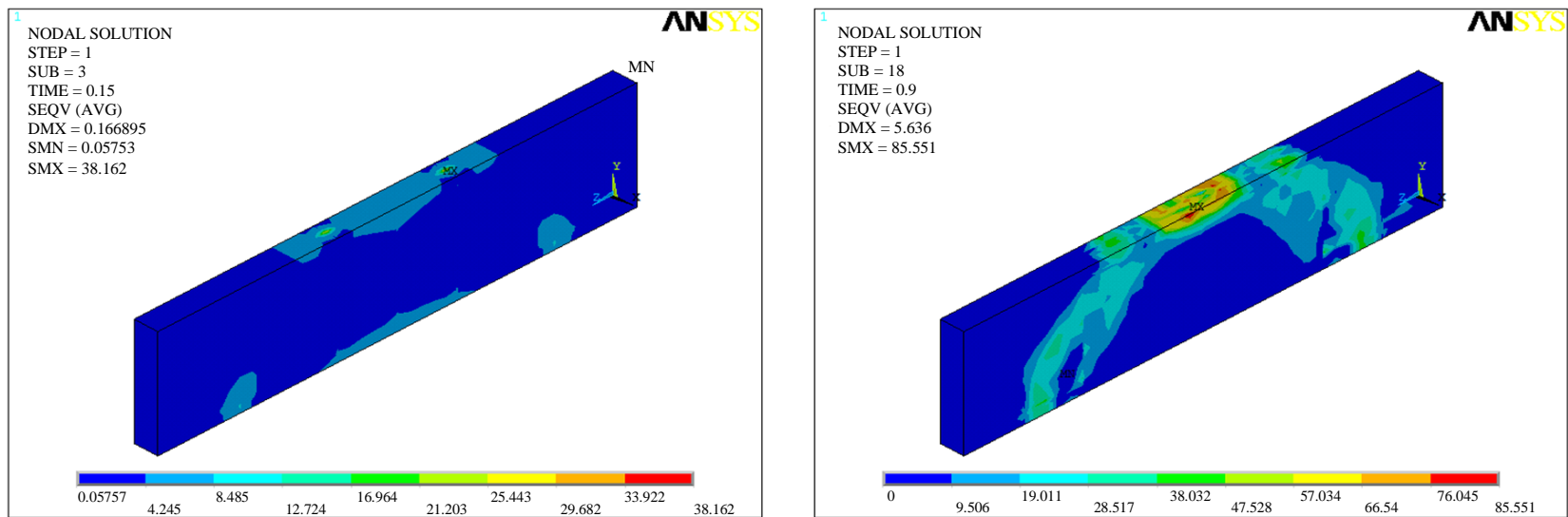

Fig. 8: DB-M1-90; first crack stress and ultimate stress

When the concrete strength is increased with the value of $70 \mathrm{MPa}$ and $80 \mathrm{MPa}$, the maximum stresses are reached the fully concrete strength by the collapse within concrete mechanism. The maximum stress is occured below the loading plate. The mechanism type of RC deep beam with $f_{c}, \stackrel{ }{=}=90 \mathrm{MPa}$ is likely bar reinforcement collapse due to under-reinforced mechanism. The stress contours of three various concrete strength beams are depicted in Figures 6-8.

From Figure 6 obtained from the stress contour, with the increment of concrete strength then the stresses that occur are also greater and the collapse is dominated by 
compressive stress however the cross section still has a slight tensile stress at the bottom of the beam so that the mechanism is determined by shear collapse.

The modelling process of the FEM software ANSYS program with the same load $P=300 \mathrm{kN}$ in addition to determine concrete yield stress, also obtained von Misses stress of bar reinforcements and strirrups at ultimate condition due to various concrete compressive strength. The tensile stress $\left(f_{t s}\right)$, compressive stress $\left(f_{c s}\right)$ and stirrup stress $\left(f_{s t}\right)$ are summarized in Table 7 below. The von Mises stress contour of bar reinforcement and stirrup are shown in Fig. 9 and 10.
Based on the pattern obtained from the stress contour, the higher the strength of the concrete, then the greater the stress on the reinforcement. The maximum stress is mostly occured on the tensile reinforcement in the middle span. Whereas for the stirrup reinforcement stress, the maximum value is in the shear region.

\section{Deflection}

The vertical deflection $\left(\delta_{m s}\right)$ obtained due to vertical point load based on FEA ANSYS with various concrete strength can be seen in Fig. 11.

Table 7: Reinforcement stress on the concrete first crack and ultimate condition

\begin{tabular}{|c|c|c|c|c|c|c|}
\hline \multirow[b]{2}{*}{ Beam ID } & \multicolumn{2}{|c|}{ Tensile steel } & \multicolumn{2}{|c|}{ Compressive steel } & \multicolumn{2}{|l|}{ Stirrups } \\
\hline & $f_{\mathrm{ts} 1}(\mathrm{MPa})$ & $f_{\mathrm{ts} 2}(\mathrm{MPa})$ & $f_{\mathrm{cs} 1}(\mathrm{MPa})$ & $f_{\mathrm{cs} 2}(\mathrm{MPa})$ & $f_{\mathrm{st} 1}(\mathrm{MPa})$ & $f_{\text {st2 }}(\mathrm{MPa})$ \\
\hline DB-M1-65 & 19.293 & 612.576 & 12.019 & 434.974 & 81.354 & 596.059 \\
\hline DB-M1-70 & 77.832 & 584.990 & 5.924 & 439.180 & 76.152 & 634.242 \\
\hline DB-M1-80 & 20.028 & 606.705 & 5.845 & 435.305 & 72.349 & 683.406 \\
\hline DB-M1-90 & 21.083 & 607.691 & 1.835 & 453.264 & 42.944 & 644.564 \\
\hline DB-M2-90 & 27.516 & 627.835 & 46.652 & 308.480 & 7.139 & 627.835 \\
\hline DB-M3-90 & 11.833 & 601.100 & 8.233 & 444.981 & 20.601 & 675.438 \\
\hline DB-M3a-90 & 9.251 & 617.474 & 43.592 & 375.291 & 19.252 & 572.268 \\
\hline DB-M3b-90 & 25.507 & 644.033 & 56.654 & 374.379 & 6.361 & 595.542 \\
\hline DB-M3c-90 & 20.152 & 625.719 & 44.731 & 435.399 & 12.818 & 652.806 \\
\hline DB-M4-90 & 27.786 & 596.833 & 46.571 & 233.781 & 12.600 & 596.833 \\
\hline
\end{tabular}

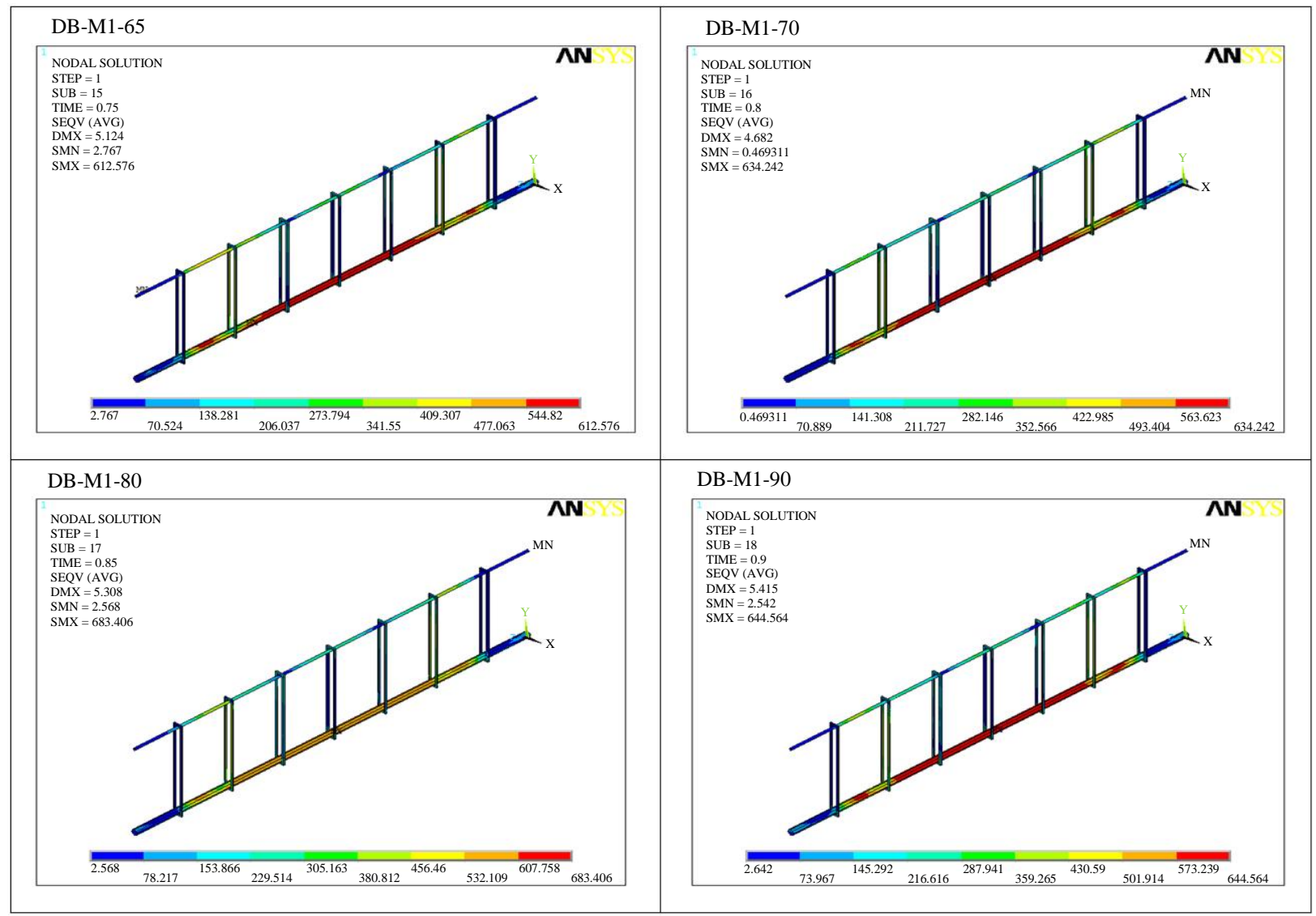

Fig. 9: Stress contour of reinforcement; model M1 


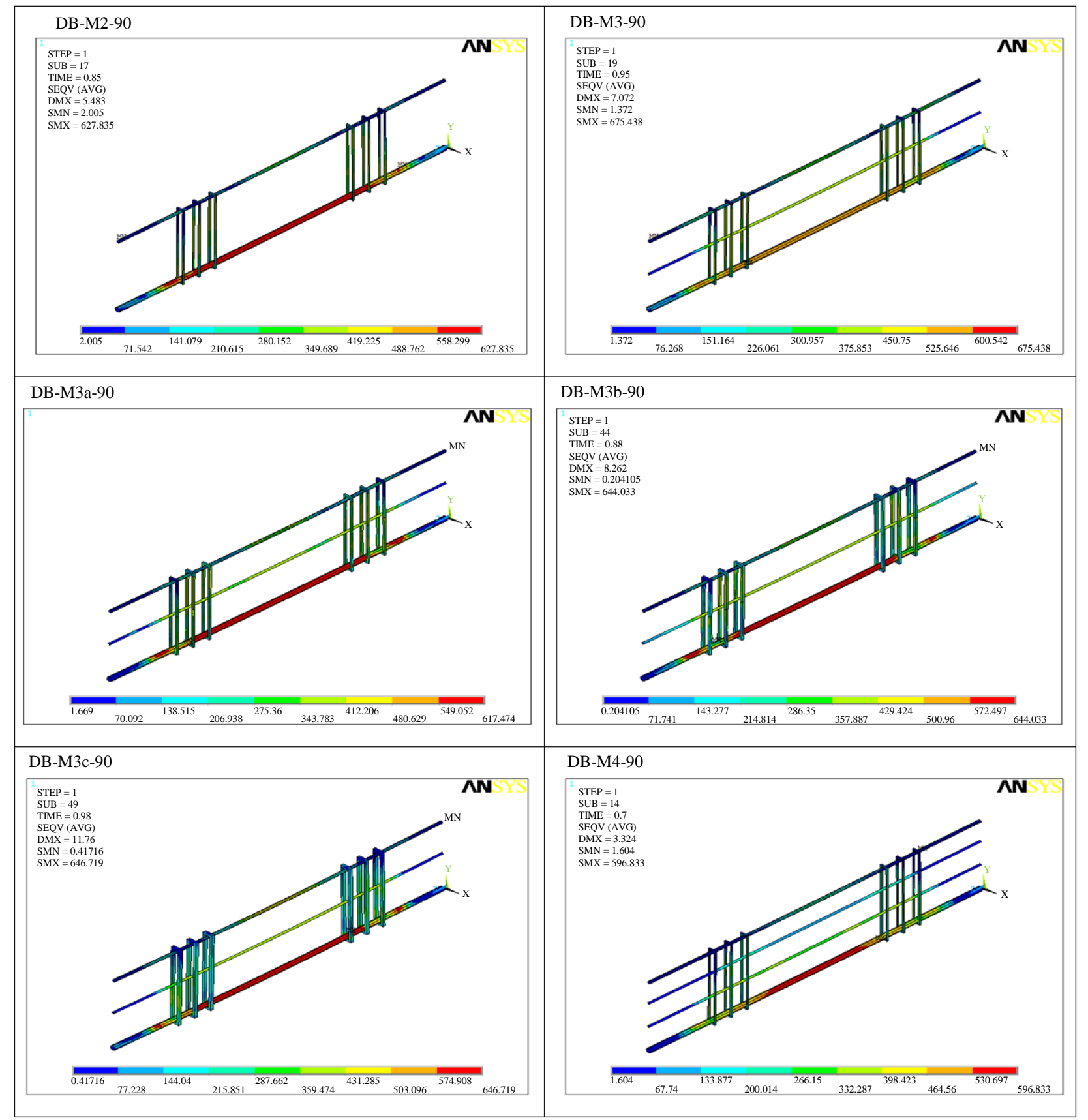

Fig. 10: Stress contour of reinforcement; model $M^{*}-90$

Plot of vertical deflection under ultimate load with various ultimate stress is shown in Fig. 12. The deflection obtained due to ultimate load under ultimate stress achieved. There are no significant changes of deflection due to various ultimate stress. Vertical deflection of $4.60 \mathrm{~mm}$ obtained with concrete strength both $80 \mathrm{MPa}$ and $90 \mathrm{MPa}$.

By additional reinforcement area (As) from 28.26 $\mathrm{mm}^{2}$ up to $100.48 \mathrm{~mm}^{2}$, dms values are obtained at the ultimate stress condition, as shown in Fig. 12.
There are no significant changes of deflection due to various reinforcement area of $28.26 \mathrm{~mm}^{2}$ and 50.24 $\mathrm{mm}^{2}$, with the values of $6.14 \mathrm{~mm}$ and $6.33 \mathrm{~mm}$, respectively. Bar diameter is enhanced with $A_{s}$ of 100.46 $\mathrm{mm}^{2}$ that maximum deflection is obtained at $10.46 \mathrm{~mm}$. The reinforcement area is doubly increasing, maximum deflection is obtained by enhancement about $30 \%$ with increased ultimate load of $540 \mathrm{kN}$ to $600 \mathrm{kN}$. Vertical displacement obtained due to various reinforcement area are depicted in Fig. 12. 


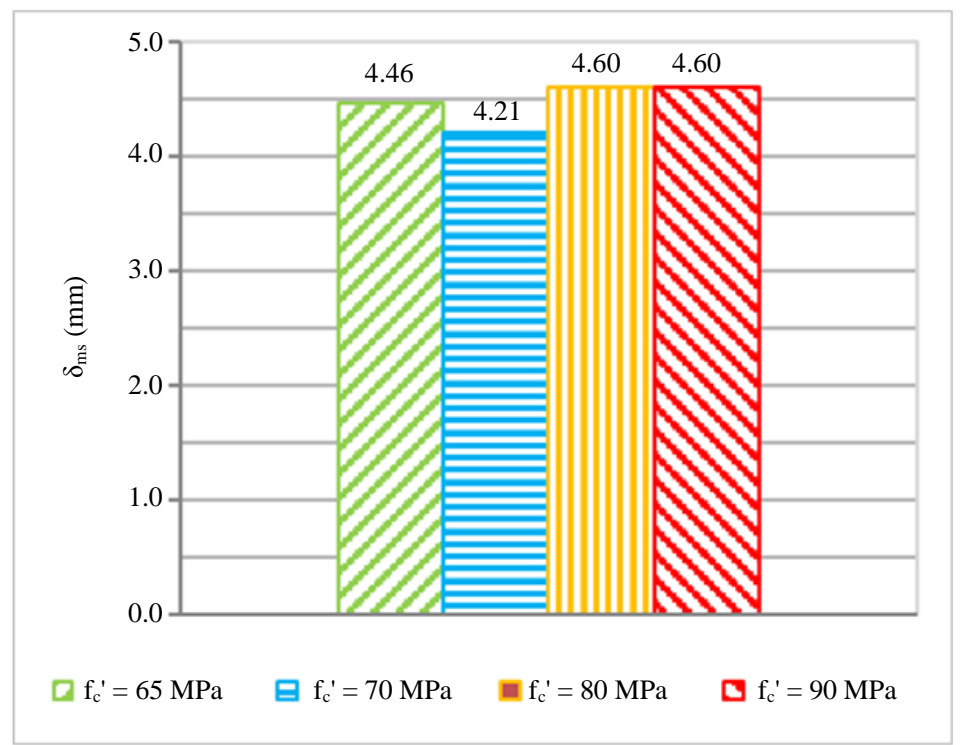

Fig. 11: Vertical deflection against concrete strength

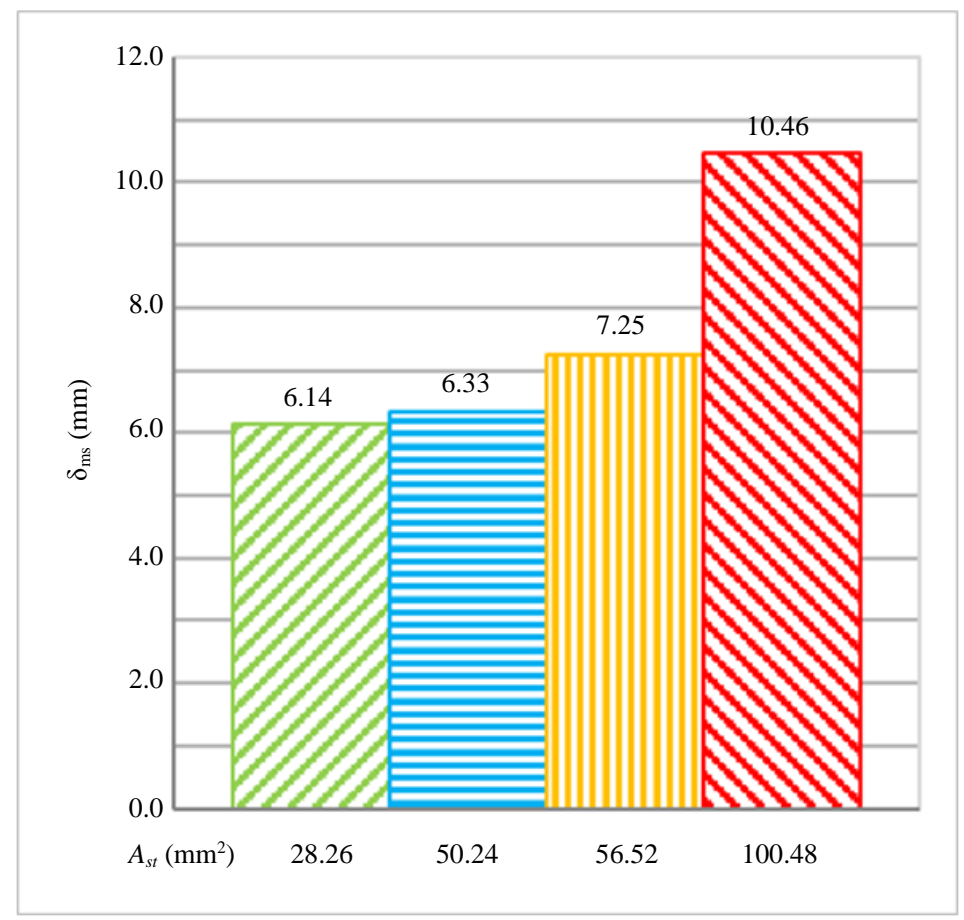

Fig. 12: Vertical deflection under various reinforcement area

\section{Concrete Crack}

The results of the stress analysis on high strength concrete deep beams on variations in concrete strength, stirrup distance and reinforcement are depicted in Table 8. For an explanation of the crack patterns that generally occured in deep beam as compressive crack, shear crack and flexural crack occured that it can be seen in Fig. 13.
The results of stress testing on HSC deep beams using FEA ANSYS can be concluded that concrete stresses and steel reinforcement in deep beams have a stress value dominated by compressive stress so that the final collapse pattern is determined by brittle shear collapse.

Based on Table 6, it can be seen with different strength of concrete, the distance of stirrups and increasing the area of stirrup reinforcement causes the stresses that occur in deep beams increased too. 
It can be seen in Fig. 10 that the first crack occurred in the middle tensile area in the form of a flexible crack and in the press area at the position of plate loading in the form of a compressive crack, then as the load step until the cracks in the beam sliding area occurred, cracking gradually spreading angles that occur between placement to plate loading, the crack pattern angles when the ultimate load forms an angle between $45^{\circ}$ to $65^{\circ}$ which causes collapse in the form of shear collapse which causes brittle collapse. Crack volume under ultimate load are depicted in the Table 9.
From Table 7, it can be seen by varying the strength of concrete, the distance of stirrups and increasing the area of stirrups causes the fracture volume to bind, even when the highest load of fully concrete collapse.

\section{Deflection}

The vertical deflection $\left(\delta_{m s}\right)$ obtained due to vertical point load based on FEA ANSYS with various concrete strength can be seen in Fig. 14.

Table 8: Cracking ultimate stress of deep beam model.

\begin{tabular}{llllr}
\hline Model ID & $f_{c}{ }^{\prime}(\mathrm{MPa})$ & $\varepsilon_{u}$ & $f_{c u}(\mathrm{MPa})$ & $(\%)$ \\
\hline DB-M1-65 & 65 & 0.0255 & 64.744 & 0.00 \\
DB-M1-70 & 70 & 0.0260 & 72.100 & 11.36 \\
DB-M1-80 & 80 & 0.0270 & 84.290 & 30.18 \\
DB-M1-90 & 90 & 0.0280 & 85.551 & 32.13 \\
DB-M2-90 & 90 & 0.0280 & 85.579 & 32.18 \\
DB-M3-90 & 90 & 0.0280 & 96.599 & 49.20 \\
DB-M3a-90 & 90 & 0.0280 & 90.144 & 39.23 \\
DB-M3b-90 & 90 & 0.0280 & 90.688 & 40.07 \\
DB-M3c-90 & 90 & 0.0280 & 97.299 & 50.28 \\
DB-M4-90 & 90 & 0.0280 & 71.459 & 10.37
\end{tabular}

Remarks: DB-M3 is the deep beam with localized stirrups and waist side reinforcement

DB-M3-90: $\mathrm{Pu}=570.0 \mathrm{kN} ; f_{c u}=96.599 \mathrm{MPa}$

DB-M3c-90: $\mathrm{Pu}=600.0 \mathrm{kN} ; f_{c u}=97.299 \mathrm{MPa}$

Maximum strength of deep beam with $f_{c}$ ' $=90 \mathrm{MPa}$

Table 9: Crack volume and ratio; under ultimate load

\begin{tabular}{lllllr}
\hline Model ID & $P_{\text {ult }}(\mathrm{kN})$ & $V_{\text {crack }}\left(\mathrm{m}^{3}\right)$ & $V_{\text {db }}\left(\mathrm{m}^{3}\right)$ & $\rho_{\text {crack }}(\%)$ & $r_{\text {crack }}^{+}(\%)$ \\
\hline DB-M1-65 & 450.0 & 0.4267 & 0.5120 & 83.33 & 0.000 \\
DB-M1-70 & 480.0 & 0.4523 & 0.5120 & 88.34 & 1.660 \\
DB-M1-80 & 510.0 & 0.4864 & 0.5120 & 95.00 & 12.284 \\
DB-M1-90 & 540.0 & 0.5035 & 0.5120 & 98.33 & 15.254 \\
DB-M2-90 & 510.0 & 0.4960 & 0.5120 & 96.88 & 13.986 \\
DB-M3-90 & 570.0 & 0.5117 & 0.5120 & 99.93 & 16.611 \\
DB-M3a-90 & 540.0 & 0.4901 & 0.5120 & 95.72 & 12.944 \\
DB-M3b-90 & 528.0 & 0.4987 & 0.5120 & 97.41 & 14.454 \\
DB-M3c-90 & 600.0 & 0.5088 & 0.5120 & 99.38 & 16.150 \\
DB-M4-90 & 540.0 & 0.5040 & 0.5120 & 98.44 & 15.349 \\
\hline
\end{tabular}

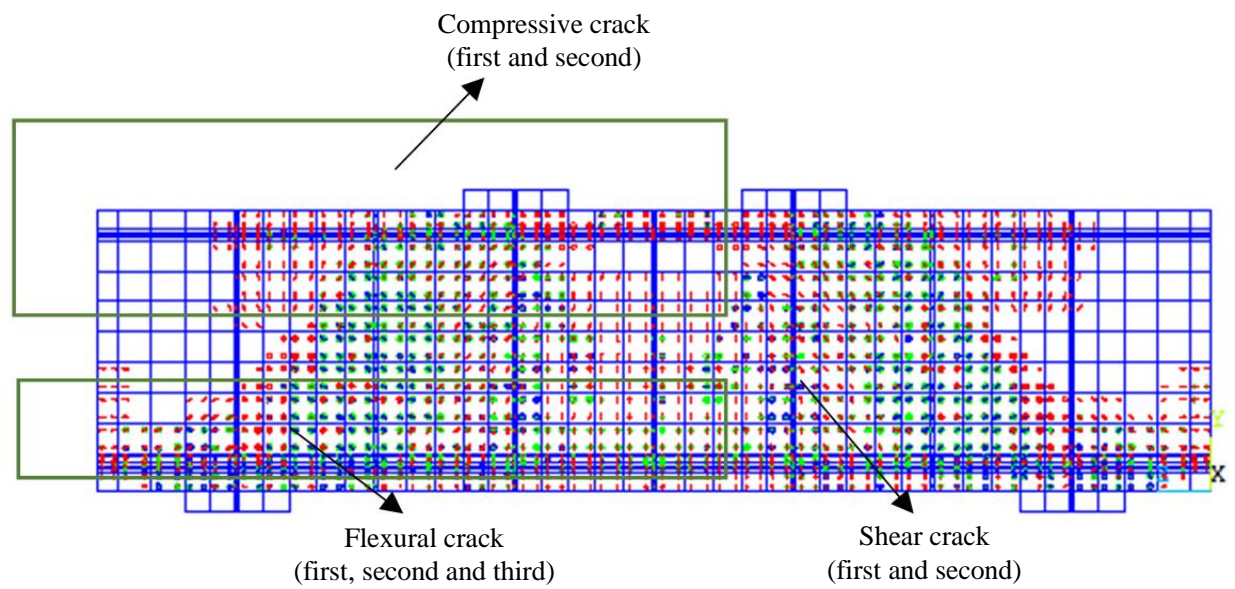

Fig. 13: Crack pattern of deep beam 


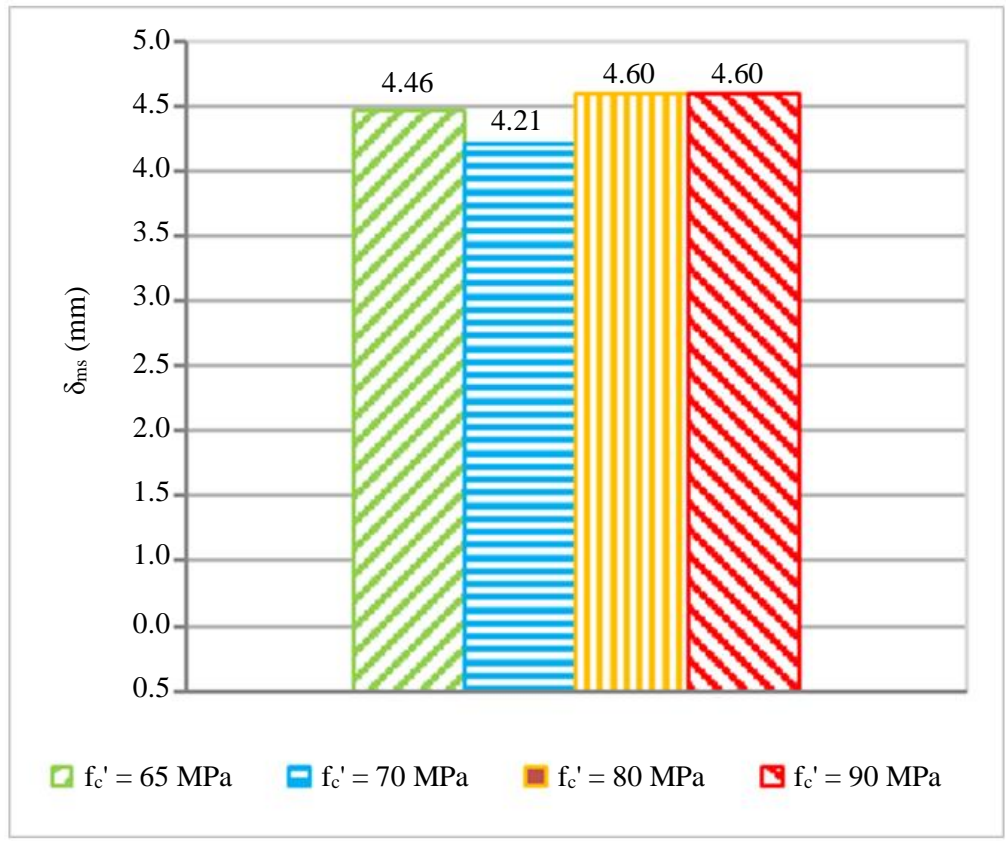

Fig. 14: Vertical deflection against concrete strength

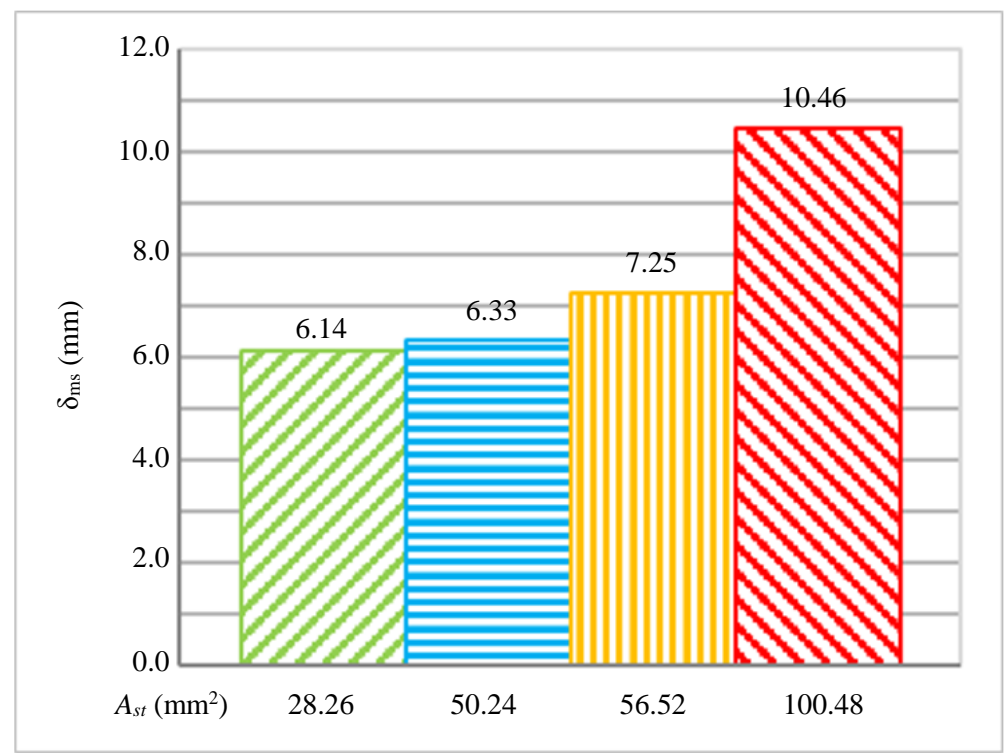

Fig. 15: Vertical deflection against reinforcement area

The deflection obtained due to ultimate load under ultimate stress achieved. There are no significant changes of deflection due to various ultimate stress. Vertical deflection of $4.60 \mathrm{~mm}$ obtained with concrete strength both $80 \mathrm{MPa}$ and $90 \mathrm{MPa}$. By additional reinforcement area $\left(A_{s}\right)$ from $28.26 \mathrm{~mm}^{2}$ up to 100.48 $\mathrm{mm}^{2}, \delta_{m s}$ values are obtained at the ultimate stress condition. These values are shown in Fig. 15.

There are no significant changes of deflection due to various reinforcement area of $28.26 \mathrm{~mm}^{2}$ and $50.24 \mathrm{~mm}^{2}$, with the values of $6.14 \mathrm{~mm}$ and $6.33 \mathrm{~mm}$, respectively. Bar diameter is enhanced with $A_{s}$ of $100.46 \mathrm{~mm}^{2}$, maximum deflection at mid span is obtained at $10.46 \mathrm{~mm}$.

The reinforcement area is doubly increasing, maximum deflection is obtained by enhancement about $30 \%$ with increased ultimate load of $540 \mathrm{kN}$ to $600 \mathrm{kN}$. Vertical displacement obtained due to various reinforcement area are depicted in Fig. 12.

Deep beam is set by concrete strength of $90 \mathrm{MPa}$ with stirrup spacing of $75 \mathrm{~mm}$ placed on the shear area. 
In order to determine the effect of side reinforcement as beam model 75(1), the ultimate stress is obtained at 83.88 $\mathrm{MPa}$, whilst no side reinforcement with same stirrup spacing at stress value of $82.98 \mathrm{MPa}$. The value of ultimate stress is shown in Fig. 16.
Based on Fig. 15 and 16, it can be seen that by adding side reinforcement on the half beam height will increase the strength of the beam in terms of deflection and stress, but the increase that occurs is not too significant, only by ranges from 10 to $20 \%$.

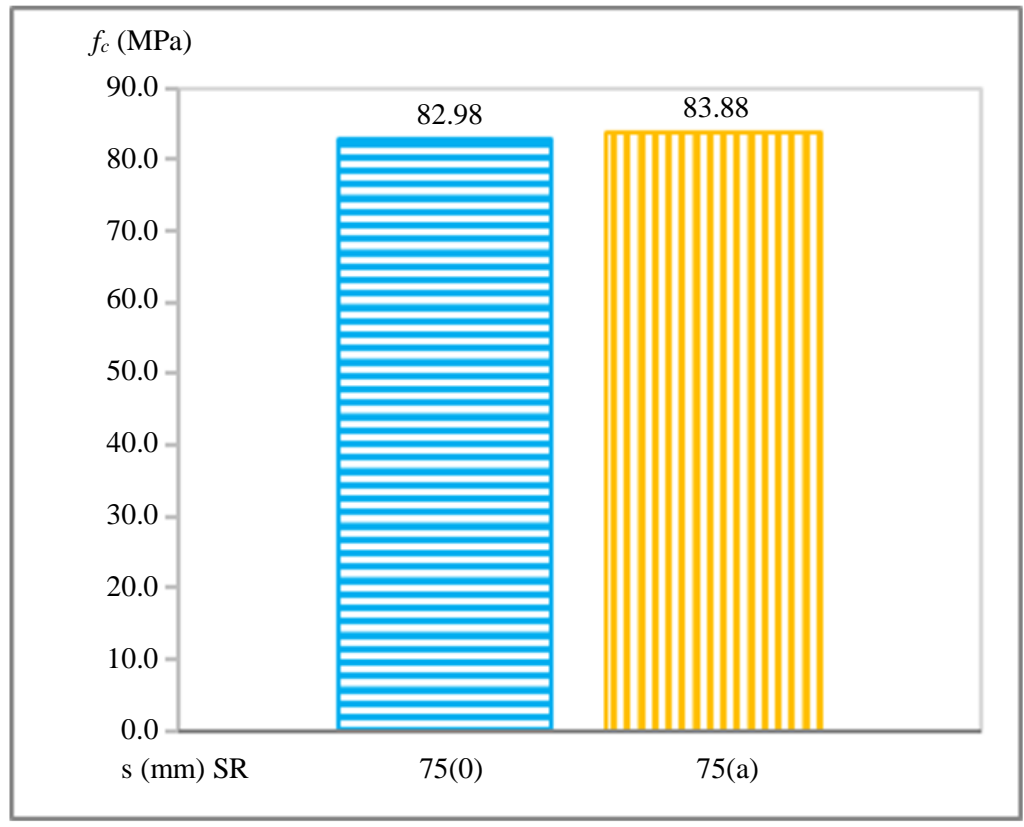

Fig. 16: Ultimate stress with or no side reinforcement

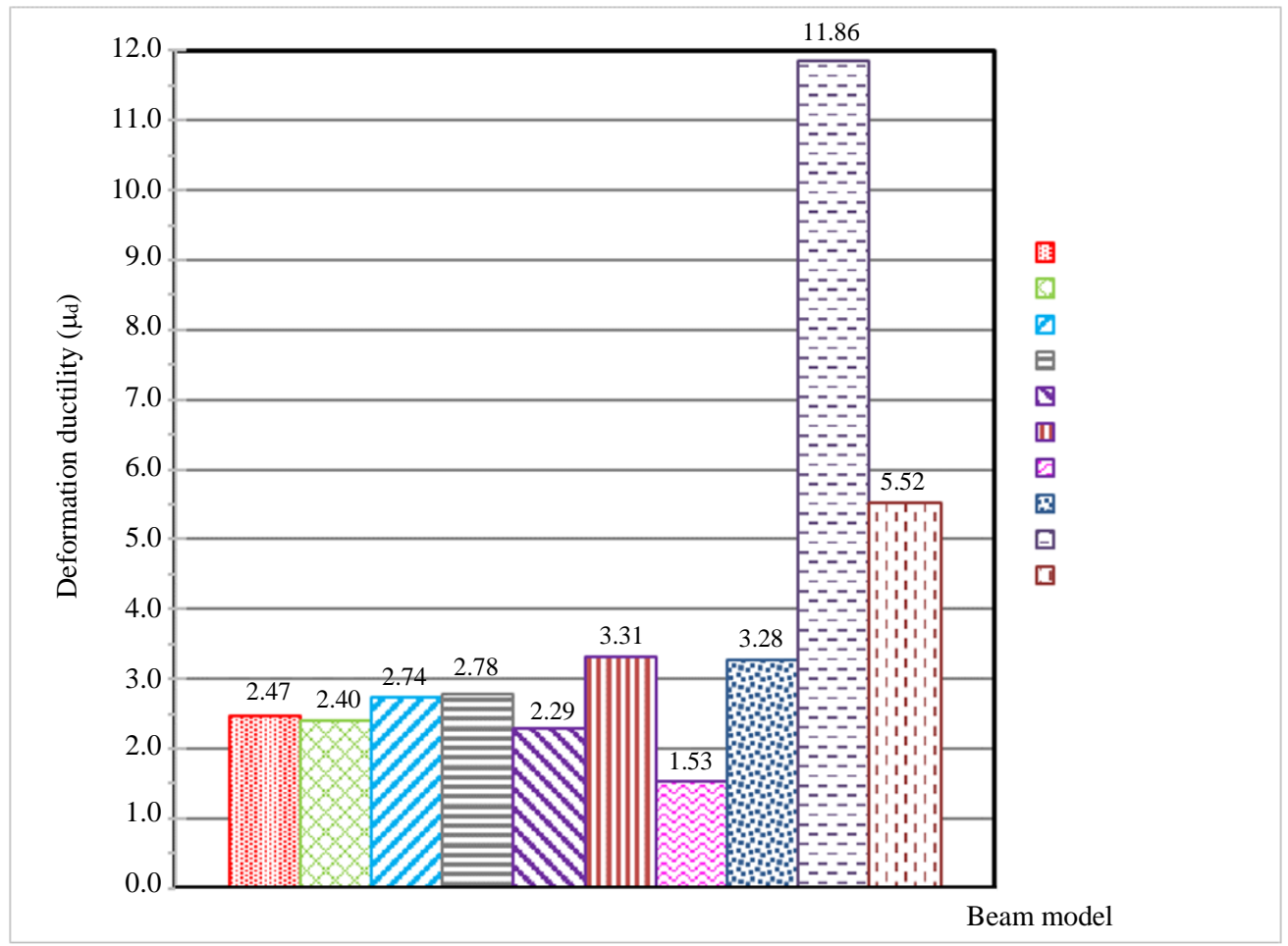

Fig. 17: Deformation ductility of HSC deep beam 
Table 10: Mid span deflection; yield and ultimate; ductility

\begin{tabular}{llllr}
\hline Beam ID & $P_{u}(\mathrm{kN})$ & $\delta_{y}(\mathrm{~mm})$ & $\delta_{u}(\mathrm{~mm})$ & $\mu_{\mathrm{d}}=\delta_{u} / \delta_{y}$ \\
\hline DB-M1-65 & 450.0 & 1.81 & 4.46 & 2.47 \\
DB-M1-70 & 480.0 & 1.75 & 4.21 & 2.40 \\
DB-M1-80 & 510.0 & 1.68 & 4.60 & 2.74 \\
DB-M1-90 & 540.0 & 1.65 & 4.60 & 2.78 \\
DB-M2-90 & 510.0 & 1.97 & 4.50 & 2.29 \\
DB-M3-90 & 570.0 & 1.85 & 6.14 & 3.31 \\
DB-M3a-90 & 540.0 & 1.93 & 6.33 & 3.28 \\
DB-M3b-90 & 528.0 & 0.64 & 7.25 & 11.26 \\
DB-M3c-90 & 600.0 & 1.89 & 10.46 & 5.52 \\
DB-M4-90 & 540.0 & 1.80 & 2.76 & 1.53 \\
\hline
\end{tabular}

\section{Deformation Ductility}

The vertical deflection under ultimate load is obtained as $\delta_{u}$ and under yield stress reached is called $\delta_{y}$. The values of mid span deflection are depicted in Table 10. Deformation ductility index is shown in Fig. 16.

Based on Fig. 17, deformation ductility of HSC deep beam is significantly influenced by reinforcement ratio, confinement and shear reinforcement. Longitudinal side reinforcement at mid height and sufficient stirrup are required to enhance restraint and ductility.

\section{Conclusion}

Based on the results of the analysis carried out on high strength concrete deep beam models with variations in the distance and diameter of the stirrup can be summarized as follows:

- The results of deflection values, stress values, crack patterns and the strength of a deep beam based on the analysis using FEA ANSYS increases with the increment of concrete compressive strength, stirrup reinforcement area and close the distance between stirrups

- By the addition of side reinforcement affects the strength of the deep beam, the more the side reinforcement increases the load that can be retained, the deep beam stress and ductility increase.

- The value of ductility will not increase significantly by only changing the strength of concrete and adding longitudinal shear reinforcement, whereas by making variable changes on the stirrup reinforcement such as close the distance and increase longitudinal reinforcement and increase the diameter of the stirrup reinforcement will greatly affect the value of ductility. So, the addition of confined shear reinforcement and increasing the diameter of the stirrup is most effective in increasing ductility of deep beam

- Behaviour of high strength concrete deep beam with localized stirrups in the shear area along with additional waist side reinforcement is likely enhanced the strength resistance of shear collapse mechanism

\section{Acknowledgement}

The present work was developed in the collaborative framework of research between Lambung Mangkurat University and Muhammadiyah University.

\section{Funding Information}

The financial support of the research grant from Lambung Mangkurat University and Muhammadiyah University is gratefully appreciated.

\section{Authors Contributions}

Syahril Taufik: Participated in all computational modeling, coordinated the data analysis and contributed to the writing of the manuscript.

Elia Anggarini: Coordinated the literature review, conducted the detailed ANSYS modeling, produced tables and graphs.

Ichwan Setiawan: Designed the research plan and organized the study.

\section{Ethics}

This article is original and contains unpublished material. The corresponding author confirms that all of the other authors have read and approved the manuscript and no ethical issues involved.

\section{References}

Aguilar, G., B.M. Adolfo, J.P.M. Gustavo, A.R. Julio and K.J. Wight, 2002. Experimental evaluation of design procedures for shear strength of deep reinforced concrete beams. ACI Structural J., 99-S56: 539-548. DOI: 10.14359/12123

Arabzadeh, A.R. and A.R.R. Aghayari, 2001. Investigation of experimental and analytical shear strength of reinforced concrete deep beams. Int. J. Civil Eng. - Structural Eng., 9: 207-214. 
Azizinamini, A., S.S.B. Kuska, P. Brungardt and E. Hatfiled, 1994. Seismic behaviour of square high strength concrete columns, ACI Structural J., 91: 336-345. DOI: 10.14359/4362

Barbosa, A.F. and O.R. Gabriel, 1998. Analysis of reinforced concrete structures using ANSYS nonlinear concrete model. CIMNE, Barcelona, Spain.

Carrasquillo, R.L., H.N. Athur and O.S. Floyd, 1981. Properties of high-strength concrete subject to shortterm loads. J. Am. Concrete Inst., 78: 171-178.

DOI: $10.14359 / 6914$

Delalibera, R.G. and J.S. Giongo, 2008. Theoritical and numerical analysis of reinforced concrete beams with confinement reinforcement. IBRACON Structures Mater., 1: 17-30. DOI: $10.1590 / \mathrm{S} 1983-41952008000100002$

Hadi, M.N.S. and J. Ross, 2008. The effects of confinement shapes on over reinforced HSC beams. Int. J. Comput. Inform. Syst. Sci. Eng., 2: 110-117.

Jang, I.Y., H.G. Park, Y.G. Kim, S.S. Kim and J.H. Kim, 2009. Flexural behavior of high-strength concrete beams confined with stirrups in pure bending zone. Int. J. Concrete Struct. Mater., 3: 39-45. DOI: 10.4334/IJCSM.2009.3.1.039

Karayannis, C.G., C.E. Chalioris and P.D. Mavroeidis, 2005. Shear capacity of RC rectangular beams with continuous spiral transversal reinforcement. Proceeding of the 12th International Conference in Computational Methods and Experimental Measurements XII - Modeling and Simulation, (MMS' 05), pp: 379-386.

Karthik, M.R.M., 2009. Stress-srain model of uncofined and confined concrete and stress-block parameters. Texas A\&M University.

Kwan, A.K.H. and J.C.M. Ho, 2010. Ductility design of high-strength concrete beams and columns. Adv. Struct. Eng., 13: 651-664.

DOI: $10.1260 / 1369-4332.13 .4 .651$
Lertsrisakulrat, T., J. Niwa, A. Yanagawa and M. Matsuo, 2002, Concepts of localized compressive failure of concrete in RC deep beams. J. Mater. Concrete Struct. Pavements, 697: 215-225. DOI: 10.2208/jscej.2002.697_215

Neville, A. and P.C. Aitcin, 1998. High performance concrete - an overview. Mater. Structures, 31: 111-117.

Noguchi, T. and K.M. Nemati, 1991. Relationship between the compressive strength and modulus of elasticity of high-strength concrete. Proceedings of the CBM-CI International Workshop, (IW' 91), Karachi, Pakistan.

Park, R. and T. Paulay, 1975, Reinforced Concrete Structures. 1st Edn., J. Wiley and Sons, New York, ISBN-10: 0471659177, pp: 800.

Sudarsana, I.K., 2006. Shear strength prediction of reinforced concrete deep beam according to strut and tie model. J. Civil Eng. Sci., 10: 35-43.

Sugianto, A. and S. Taufik, 2008, Numerical modelling behaviour of reinforced concrete deep beam with strut-and-tie model. Int. J. Mechan. Applic., 8: 1-9.

Tjitradi, D., E. Eliatun and S. Taufik, 2017. 3D ANSYS numerical modeling of reinforced concrete beam behavior under different collapsed mechanism. Int. J. Mechan. Applic., 7: 14-23.

Wight, J.K. and J.G. MacGregor, 2009. Reinforced Concrete: Mechanics and Design. 5th Edn., Prentice Hall, New Jersey, NJ., ISBN-10: 0132281414, pp: 1112 .

Wolanski, A.J., 2004. Flexural behavior of reinforced and restressed concrete beams using finite element analysis. M.Sc. Theses, Faculty of the Graduate School, Arquette University, Milwaukee, Wisconsin.

Wu, Z., 2006. Behavior of high-strength concrete members under pure flexure and axial-flexural loadings. Dissertation Civil Engineering North Carolina State University. Raleigh, North Carolina. 